\title{
RESEARCH
}

Open Access

\section{Human levator veli palatini muscle: a novel source of mesenchymal stromal cells for use in the rehabilitation of patients with congenital craniofacial malformations}

Daniela Franco Bueno ${ }^{1,2^{*}}$ (D), Gerson Shigueru Kabayashi ${ }^{3}$, Carla Cristina Gomes Pinheiro ${ }^{1}$, Daniela Y. S. Tanikawa ${ }^{1,2}$, Cassio Eduardo Raposo-Amaral ${ }^{4}$, Diogenes Laercio Rocha ${ }^{1}$, José Ricardo Muniz Ferreira ${ }^{5}$, Yoichiro Shibuya ${ }^{6}$, Akishige Hokugo ${ }^{6}$, Reza Jarrahy ${ }^{6}$, Patricia A. ZuK ${ }^{6}$ and Maria Rita Passos-Bueno ${ }^{3}$

\begin{abstract}
Background: Bone reconstruction in congenital craniofacial differences, which affect about 2-3\% of newborns, has long been the focus of intensive research in the field of bone tissue engineering. The possibility of using mesenchymal stromal cells in regenerative medicine protocols has opened a new field of investigation aimed at finding optimal sources of multipotent cells that can be isolated via non-invasive procedures. In this study, we analyzed whether levator veli palatini muscle fragments, which can be readily obtained in non-invasive manner during palatoplasty in cleft palate patients, represent a novel source of MSCs with osteogenic potential.
\end{abstract}

Methods: We obtained levator veli palatini muscle fragments $\left(3-5 \mathrm{~mm}^{3}\right)$, during surgical repair of cleft palate in 5 unrelated patients. Mesenchymal stromal cells were isolated from the muscle using a pre-plating technique and other standard practices. The multipotent nature of the isolated stromal cells was demonstrated via flow cytometry analysis and by induction along osteogenic, adipogenic, and chondrogenic differentiation pathways. To demonstrate the osteogenic potential of these cells in vivo, they were used to reconstruct a critical-sized fullthickness calvarial defect model in immunocompetent rats.

Results: Flow cytometry analysis showed that the isolated stromal cells were positive for mesenchymal stem cell antigens (CD29, CD44, CD73, CD90, and CD105) and negative for hematopoietic (CD34 and CD45) or endothelial cell markers (CD31). The cells successfully underwent osteogenic, chondrogenic, and adipogenic cell differentiation under appropriate cell culture conditions. Calvarial defects treated with CellCeram ${ }^{\text {TM }}$ scaffolds seeded with the isolated levator veli palatini muscle cells showed greater bone healing compared to defects treated with acellular scaffolds.

\footnotetext{
* Correspondence: dbuenousp@gmail.com; daniela.fbueno@icloud.com ${ }^{1}$ Hospital Sírio-Libanês, Instituto de Ensino e Pesquisa, São Paulo, SP, Brazil ${ }^{2}$ Hospital Municipal Infantil Menino Jesus, São Paulo, SP, Brazil

Full list of author information is available at the end of the article
}

C C The Author(s). 2020 Open Access This article is licensed under a Creative Commons Attribution 4.0 International License, which permits use, sharing, adaptation, distribution and reproduction in any medium or format, as long as you give appropriate credit to the original author(s) and the source, provide a link to the Creative Commons licence, and indicate if changes were made. The images or other third party material in this article are included in the article's Creative Commons licence, unless indicated otherwise in a credit line to the material. If material is not included in the article's Creative Commons licence and your intended use is not permitted by statutory regulation or exceeds the permitted use, you will need to obtain permission directly from the copyright holder. To view a copy of this licence, visit http://creativecommons.org/licenses/by/4.0/ The Creative Commons Public Domain Dedication waiver (http://creativecommons.org/publicdomain/zero/1.0/) applies to the data made available in this article, unless otherwise stated in a credit line to the data. 
(Continued from previous page)

Conclusion: Cells derived from levator veli palatini muscle have phenotypic characteristics similar to other mesenchymal stromal cells, both in vitro and in vivo. Our findings suggest that these cells may have clinical relevance in the surgical rehabilitation of patients with cleft palate and other craniofacial anomalies characterized by significant bone deficit.

Keywords: Bone reconstruction, Mesenchymal stromal cells, Levator veli palatini muscle, Osteogenic differentiation, Scaffold, Craniofacial malformations

\section{Introduction}

The therapeutic potential of mesenchymal stromal cells in bone tissue engineering is promising, as their use may allow for the reconstruction of complex bone defects without the need for associated donor site morbidity, which is a distinct limitation when autologous bone grafts are used. It is expected that, once effective and uniform protocols are adapted clinically, bone tissue engineering will be used to treat a wide variety of conditions that present with bone deficit as a primary condition, including congenital malformations, or in the management of patients with secondary bone loss, as in the setting of trauma, oncologic resection, or osteoporosis.

Bone reconstruction in craniofacial diseases, which affect about $2-3 \%$ of newborns, has historically been the focus of intensive research [1]. Due to its high incidence rate, estimated to occur in approximately 1:2500 live births [2, 3], cleft palate (CP) stands out as one of the most intensively researched malformations.

In approximately $50 \%$ of cases, CP occurs as an isolated entity, while the remainder of cases are associated with various syndromes in which other structures are affected [4]. In these syndromic cases, patients may exhibit other facial bone malformations that require surgical correction, as in the case of Treacher-Collins syndrome [5] and Goldenhar syndrome [6]. The current "gold standard" approaches to facial skeletal reconstruction in these patient populations include the use of autogenous bone grafts and distraction osteogenesis $[5,6]$. However, the benefits of these surgical procedures may be offset by complications such as donor site morbidity, postsurgical reabsorption, and infection $[7,8]$. To circumvent these problems, researchers have focused on the development of bone tissue engineering strategies using various combinations of osteogenic materials, growth factors, and stem cells that may offer alternative methods with comparatively minimal or no donor site morbidity and lower overall complication profiles [9-12]. We previously reported that orbicularis oris muscle (OOM) fragments, obtained during cheiloplasty of patients with cleft lip (CL) patients, are a rich source of mesenchymal stem cells (MSCs) that may be useful for bone reconstruction when associated with a collagen scaffold [13].
However, up to $50 \%$ of CP cases are associated with craniofacial syndromes characterized by significant bone defects, yet occur in the absence of a CL deformity, where OOM is therefore not readily accessible during surgical repair of the palate. We were therefore prompted to investigate whether another regional source of muscle cells-the levator veli palatini muscle (LVPM) - might provide an alternative source of clinically relevant MSCs. Like OOM during cleft lip repair, LVPM can be easily obtained during planned palatoplasty in CP patients and can therefore represent an advantageous source of MSC for use in tissue engineering protocols.

Here, we describe the isolation and characterization of stromal cells from this new source, with the overarching and ultimate goal of using these cells in the surgical rehabilitation of patients with craniofacial syndromes associated with CP.

\section{Material and methods}

Signed informed consent from all participants in this study was obtained from each patient or their legal parent or guardian(s). Study approval was granted by the Ethics Committee of the Biosciences Institute of the University of São Paulo. The laboratory experiments were carried out at Hospital Sírio-Libanês and the $\mathrm{Hu}$ man Genome Research Center in São Paulo, Brazil, and at the Regenerative Bioengineering and Repair (REBAR) Laboratory, Department of Surgery, Division of Plastic and Reconstructive Surgery at the David Geffen School of Medicine at UCLA.

LVPM fragments $(n=5)$ measuring $3-5 \mathrm{~mm}^{3}$ were obtained during palatoplasty in five individual $\mathrm{CL} / \mathrm{P}$ patients undergoing modified von Langenbeck repair with intravelar veloplasty (Fig. 1a, b) [14]. Surgical procedures were performed at Hospital Municipal Infantil Menino Jesus, São Paulo, Brazil, and at Sobrapar Hospital, Campinas, Brazil. LVPM fragments that were harvested at the two hospitals were transported to Sírio-Libanês Hospital Laboratory.

According to local regulatory committees and pursuant to the relevant Brazilian Laws regulating advanced cell therapies (National Sanitary Vigilance AgencyANVISA-RDC n214, February 8, 2018), all tissues were 

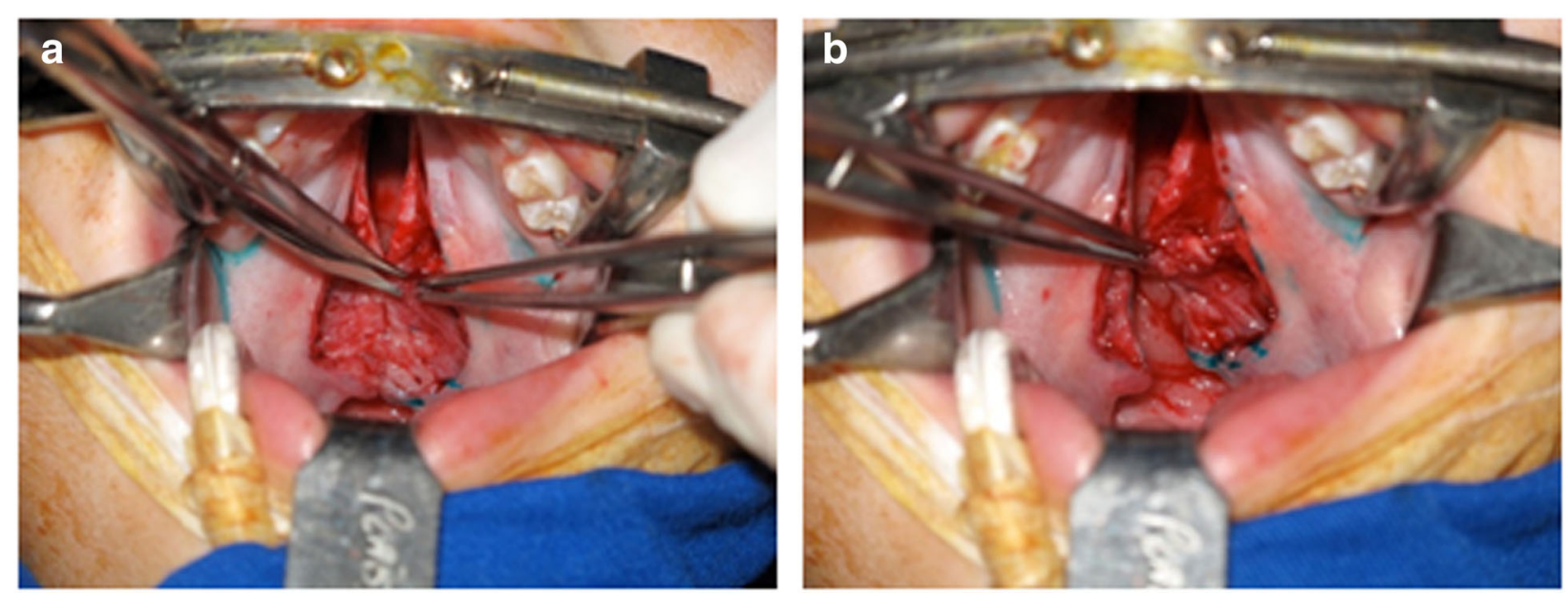

Fig. 1 Levator veli palatini muscle (a, white arrow) and small piece levator veli palatini muscle harvested to obtain the cell cultures after palatoplasty (b, blue arrow)

processed at the Sírio-Libanês Hospital Laboratory facilities using clean room infrastructure, air particulate control (HEPA filter) and airflow, and standard best practices for scientific investigation. These include the use of an antechamber for donning and doffing of personal protective equipment (PPE), the exclusive processing of human cells and tissues at the laboratory site, and the use of certified prion-free and apyrogenic reagents for cell isolation and cryopreservation, based on guidelines for stem cell research and the development of new clinical therapies as set forth by the International Society for Stem Cell Research (ISSR, www.issr.org).

Each muscle sample was collected in HEPES-buffered Dulbecco's modified Eagle's medium/Hams F-12 1:1 (DMEM/F-12; Invitrogen, Carlsbad, CA) with $200 \mathrm{U} / \mathrm{mL}$ penicillin (Invitrogen, Carlsbad, CA) and $200 \mu \mathrm{g} / \mathrm{mL}$ streptomycin (Invitrogen, Carlsbad, CA), kept in $4{ }^{\circ} \mathrm{C}$, and processed within $24 \mathrm{~h}$. All LVPM samples were washed twice in phosphate-buffered saline (PBS, Gibco, Invitrogen, Carlsbad, CA), finely minced with a scalpel, put inside a $15-\mathrm{mL}$ centrifuge tube, and incubated in 5 $\mathrm{mL}$ of TrypLE Express, (Invitrogen, Carlsbad, CA) for $30 \mathrm{~min}$, at $37^{\circ} \mathrm{C}$. Subsequently, supernatant was removed with a sterile transfer pipette, washed once with $7 \mathrm{~mL}$ of DMEM/F-12 supplemented with $10 \%$ fetal bovine serum (FBS, HyClone, Hyclone Laboratories, Logan, UT), and pelleted by centrifugation at $400 \times g$ for $5 \mathrm{~min}$ at room temperature. The pellets were resuspended and cultured in 35-mm Petri dishes (Corning, NY) containing DMEM/F-12 culture medium with $15 \%$ FBS, $2 \mathrm{mM} \mathrm{L-}$ glutamine, $2 \mathrm{mM}$ non-essential amino acids, $100 \mathrm{U} / \mathrm{mL}$ penicillin, and $100 \mu \mathrm{g} / \mathrm{mL}$ streptomycin (Invitrogen, Carlsbad, CA). After 2 weeks, cells were washed with PBS, then dissociated in trypsin solution and seeded at $1.0 \times 10^{4}$ cells per $25 \mathrm{~cm}^{2}$ for the first passage. In order to prevent cell differentiation, cultures were maintained semi-confluent and they were subcultured every 4-5 days, with medium changes every 2-3 days. After 3-4 passages, cultures yielded between $4 \times 10^{6}$ and $8 \times 10^{6}$ LVPMDSC.

The automated microbial detection system Bact/Alert TM 3D (Bact/Alert, BioMérieux, Durham, NC) was used to analyze the presence of aerobic and anaerobic bacteria and fungi in culture, and MycoAlertTM (MycoAlert PLUS Mycoplasma detection Kit-Lonza, Basel, Switzerland) was use for mycoplasma surveillance. Any cultures with a positive test suggesting infection were discarded.

\section{Flow cytometry}

Flow cytometry analysis was performed by flow cytometry in a FACSCalibur flow cytometer (BD, Becton Dickinson, Franklin Lakes, NJ) and analyzed in the CellQuest program (BD, Becton Dickinson, Franklin Lakes, NJ). Cells were pelleted, resuspended in PBS (Gibco-Invitrogen, Carlsbad, CA) at a concentration of $1.0 \times 10^{6}$ cells/ $\mathrm{mL}$, and stained with saturating concentration of antibodies. After a 45-min incubation in the dark at room temperature, cells were washed three times with PBS and resuspended in $0.25 \mathrm{~mL}$ of cold PBS. In order to analyze expression of typical cell surface markers, cells were treated with the following anti-human conjugated antibodies: CD29-PE, CD31-PE, CD34-FITC, CD44-PE, CD45-FITC, CD73-FITC, CD90-PE, CD105-FITC, and 7-amino-actinomycin D (7-AAD) staining for viability analysis (Becton Dickinson, Franklin Lakes, NJ). 7-AAD was used for the exclusion of non-viable cells in combination with PE (phycoerythrin), and FITC conjugated antibodies in flow cytometry analysis. Unstained cells were gated on forward scatter to eliminate particulate 
debris and clumped cells. A minimum of 5000 events were acquired for each sample.

\section{Mesenchymal stromal cell differentiation}

To evaluate the properties of mesenchymal stromal cell differentiation, adherent cells (4th passage) underwent in vitro adipogenic, chondrogenic, and osteogenic differentiation according to the following protocols:

\section{Adipogenic differentiation}

Cells were seeded into 6-well plates (Corning Inc., Corning, NY), at a density of $2.0 \times 10^{5}$ cells/well, in DMEM/ High Glucose (Invitrogen, Carlsbad, CA), supplemented with 10\% FBS (Hyclone, Hyclone Laboratories, Logan, UT), $1 \mu \mathrm{M}$ dexamethasone, $100 \mu \mathrm{M}$ indomethacin, $500 \mu \mathrm{M}$ 3-isobutyl-1-methylxanthine, and $10 \mu \mathrm{g} / \mathrm{mL}$ insulin (all from Sigma-Aldrich, St. Louis, MO).

Fifteen days after induction, Oil Red-O (Sigma-Aldrich, St. Louis, MO) staining was used to identify intracellular accumulation of lipid-rich vacuoles [13]. Briefly, cells were fixed with $4 \%$ paraformaldehyde in PBS for $30 \mathrm{~min}$, washed with PBS, and stained with a working solution of $0.16 \%$ Oil Red-O in PBS for 20 min [13].

\section{Chondrogenic differentiation}

Approximately $2.5 \times 10^{5}$ cells were centrifuged in a 15$\mathrm{mL}$ polystyrene tube at $400 \times \mathrm{g}$ for $5 \mathrm{~min}$, and the pellet was resuspended in $10 \mathrm{~mL}$ of basal medium. The basal medium consisted of DMEM/High Glucose (Invitrogen, Carlsbad, CA) supplemented with $1 \%$ insulin, transferrin, selenite (ITS Premix, Becton Dickinson, Franklin Lakes, NJ), 1\% $100 \mathrm{nM}$ dexamethasone (Sigma-Aldrich, St. Louis, MO), $1 \mathrm{mM}$ sodium pyruvate (Gibco-Invitrogen, Carlsbad, CA), and $50 \mu \mathrm{M}$ ascorbic acid-2 phosphate (Sigma-Aldrich, St. Louis, MO).

Without disrupting the pellet, cells were resuspended in $0.5 \mathrm{~mL}$ of chondrogenic medium, consisting of basal medium supplemented with $10 \mathrm{ng} / \mathrm{mL}$ transforming growth factor (TGF) $\beta 1$ (R\&D Systems, Minneapolis, $\mathrm{MN}$ ) and $10 \% \mathrm{FBS}$, and maintained in a humidified atmosphere with $5 \% \mathrm{CO}_{2}$ at $37^{\circ} \mathrm{C}$.

On day 1 , tubes were gently turned over to acquire a single floating cell sphere. Medium was changed every 4 days. On day 21 , samples were fixed in $10 \%$ formalin for $24 \mathrm{~h}$ at $4{ }^{\circ} \mathrm{C}$ and paraffin-embedded.

Cryosections ( $5 \mu \mathrm{m}$ thick) were cut from the harvested micromasses and stained with toluidine blue to demonstrate extracellular matrix mucopolysaccharides [13].

\section{Osteogenic differentiation}

LVPM cells were cultured in osteogenic medium containing DMEM/Low Glucose (Invitrogen, Carlsbad, CA) with $0.1 \mu \mathrm{M}$ dexamethasone and $50 \mu \mathrm{M}$ ascorbic acid 2phosphate. On day $9, \beta$-glycerolphosphate $(10 \mathrm{mM})$ was added to induce mineralization. On day 11, calcium content was evaluated by a Calcium Detection Assay kit (Abcam, Cambridge, UK) according to the company manual. On day 21, Alizarin Red staining was performed in order to identify accumulation of mineralized calcium. The wells were washed twice with PBS, and briefly, cells were fixed with $70 \%$ ethanol (Sigma-Aldrich, St. Louis, $\mathrm{MO}$ ) for $30 \mathrm{~min}$. After fixation, the wells were stained with $0.2 \%$ Alizarin Red S solution (pH 4.2; SigmaAldrich, St. Louis, MO) for $30 \mathrm{~min}$. For the final wash, each well was washed with PBS (Gibco Invitrogen, Grand Island, NY) three times [15].

\section{Immunocompetent rat calvarial defect model}

The Animal Research Ethics Committee at the University of São Paulo approved the use of Wistar immunocompetent 9-month-old male rats, body weight 320$420 \mathrm{~g}$, in this experimental protocol $(n=5)$. The animals were kept in ventilated stands (Alesco, São Paulo, Brazil), in standardized air and light conditions, at a constant temperature of $22^{\circ} \mathrm{C}$ with a 12-h light/day cycle. They had free access to drinking water and standard laboratory food pellets.

The animals were anesthetized with an intraperitoneal injection $(0.3 \mathrm{~mL} / 100 \mathrm{~g}$ of body weight) using a combination of ketamine hydrochloride (5\%) and xylazine (2\%). The heads of the rats were positioned in a cephalostat during the surgical procedure. A midline skin incision was performed from the nasofrontal area to the external occipital protuberance. The skin and underlying tissues, including the periosteum and the temporalis muscles, were reflected laterally to expose the full extent of the calvaria.

We next performed two symmetric full-thickness cranial defects of $4 \mathrm{~mm}$ diameter in size on each parietal region of the animals. The cranial defect was created with a 4-mm-diameter trephine drill, and constant irrigation with sterile physiological solution was used to prevent overheating of the bone.

The left sides (LS) of the skulls were arbitrarily selected as the control sides and were reconstructed with CellCeram $^{\text {Tw }}$ scaffolds (Scaffdex, Finland). By comparison, the right-sided defects (RS) were reconstructed with CellCeram $^{\text {Tw }}$ scaffolds that were seeded with $1 \times 10^{5}$ undifferentiated LVPM stem cells. Scalps were repaired with 4-0 nylon sutures (Ethicon, São Paulo, Brazil), and the animals euthanized 30 days after cell transplantation. Calvaria were harvested for analysis at the time of euthanasia.

\section{Fabrication of scaffold carriers}

CellCeram $^{\text {Ta }}$ (Scaffdex, Finland) was designed in a cylindrical shape with $4 \mathrm{~mm}$ diameter of a bioabsorbable $60 \%$ hydroxyapatite and $40 \% \quad ß$-tricalciumphosphate 
composite with a foam-type structure of $83 \%$ average porosity, and $200-400 \mu \mathrm{m}$ of average pore size, with an overall range of $100-800 \mu \mathrm{m}$. The dimensions of the scaffolds were designed to match the planned calvarial rat defects in these experiments.

\section{Cell preparation for transplantation procedure}

We used CellCeram ${ }^{\text {Tx }}$ (Scaffdex, Finland) as a framework to seed $10^{5}$ undifferentiated LVPM stem cells and placed on a $35-\mathrm{mm}$ plate (6-well plate; Corning, NY). The cells were supplemented with $2.5 \mathrm{~mL}$ of medium used for undifferentiated LVPM stem cells and incubated at $37^{\circ} \mathrm{C}$ and $5 \% \mathrm{CO}_{2}$ for $24 \mathrm{~h}$ prior to transplantation in order to adhere to the scaffold.

CellCeram $^{\text {Tw }}$ scaffolds with adherent LVPM stem cells were transferred to the right cranial bone defect, and the cell-bearing CellCeram ${ }^{\mathrm{mm}}$ surface was positioned in direct contact with the dura mater.

\section{Histological preparation and quantitative analysis}

The calvaria of the animals were harvested for histological assessment following euthanasia at day 30 following surgery. Tissue samples were fixed in $10 \%$ formalin solution for $24 \mathrm{~h}$, decalcified in $5 \%$ formic acid for $48 \mathrm{~h}$, and paraffin-embedded. For the morphological study, 5$\mu \mathrm{m}$ sections were stained with hematoxylin and eosin (HE) and examined under a conventional light microscope.

Quantification for regenerated bone was performed using Image (NIH, Bethesda, MD) with reference to the methods established in published manuscripts [16, 17]. Briefly, the split channel function was used to split the original RGB image into red, blue, and green channels. Then, the blue channel image was subtracted from the red one and the threshold range was set to 53-255, comparing to original HE images to include all regenerated bone tissue into the positive region. Then, range of interest (ROI) for all the bone defect and regenerated bone tissue was selected with the polygon selection function. Finally, the percent area of positive region in ROI which was regenerated bone was determined.

\section{Immunohistochemistry}

The sections were deparaffinized with two 5-min washes in xylene, hydrated in graded ethanol series, and then rinsed in distilled water. For antigen retrieval, slides were incubated for $40 \mathrm{~min}$ in citrate buffer $\left(95-100^{\circ} \mathrm{C}\right)$ and then cooled for $20 \mathrm{~min}$ at room temperature, rinsed in PBS, and blocked for $1 \mathrm{~h}$ in immunofluorescent blocking buffer (IBB-5\% BSA, 10\% FBS, $1 \times$ PBS, and 0.1\% Triton $\mathrm{X}$-100). Samples were then incubated for $1 \mathrm{~h}$ at room temperature with 1:100 mouse anti-human nuclei monoclonal antibody (HuNu; Chemicon, Temecula, CA), washed with PBS, and incubated with secondary antibody (1:600 Alexa Fluor 594 anti-mouse IgG; Thermo Fisher Scientific) for $1 \mathrm{~h}$ at room temperature. Tissue was counterstained with diamidino-2phenylindole (DAPI) (Thermo Fisher Scientific) and mounted using ProLong anti-fade (Thermo Fisher Scientific).

\section{Results}

After the first enzymatic dissociation, between 5 and 7 days of culture, adherent cells were characterized by homogeneous cell layers with a MSC-like phenotype. All cell strains were successfully expanded, frozen, and thawed several times with no visible phenotypic alterations (Fig. 2).

\section{Flow cytometry analysis}

None of the 5 LVPM cell populations expressed the CD34 and CD45 hematopoietic lineage marker or the CD31 endothelial marker. The majority of cells expressed high levels of adhesion markers (CD29, CD44, and CD90) and MSC markers (CD73 and CD105) (Fig. 3; Table 1). These results indicate that the cells obtained from LVPM were mesenchymal in nature. The LVPM cells have shown more $90 \%$ the live cells.

\section{Multilineage differentiation}

Multilineage differentiation was performed for 5 independent samples of LVPM cells. No obvious qualitative differences in their differentiation potential were observed.

The plasticity of adherent cells obtained from LVPM was assessed 3 weeks after in vitro induction of osteogenic and chondrogenic differentiation. The adipogenic differentiation was observed after 15 days. The LVPM cells from all 5 strains were able to undergo chondrogenic, adipogenic, and osteogenic differentiation in vitro (Fig. 4). Together, these results confirmed the

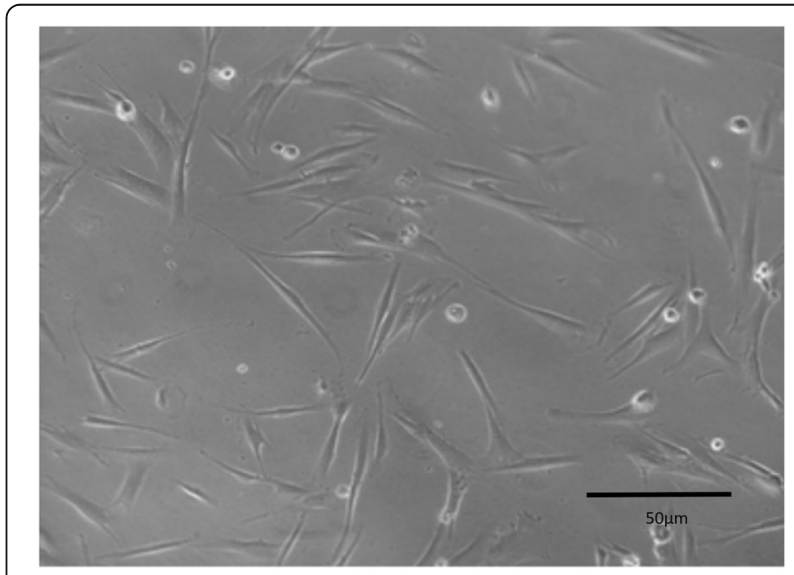

Fig. 2 Levator veli palatini muscle-derived stem cell (LVPMDSC) fibroblast-like morphology. Scale bars, $50 \mu \mathrm{m}$ 


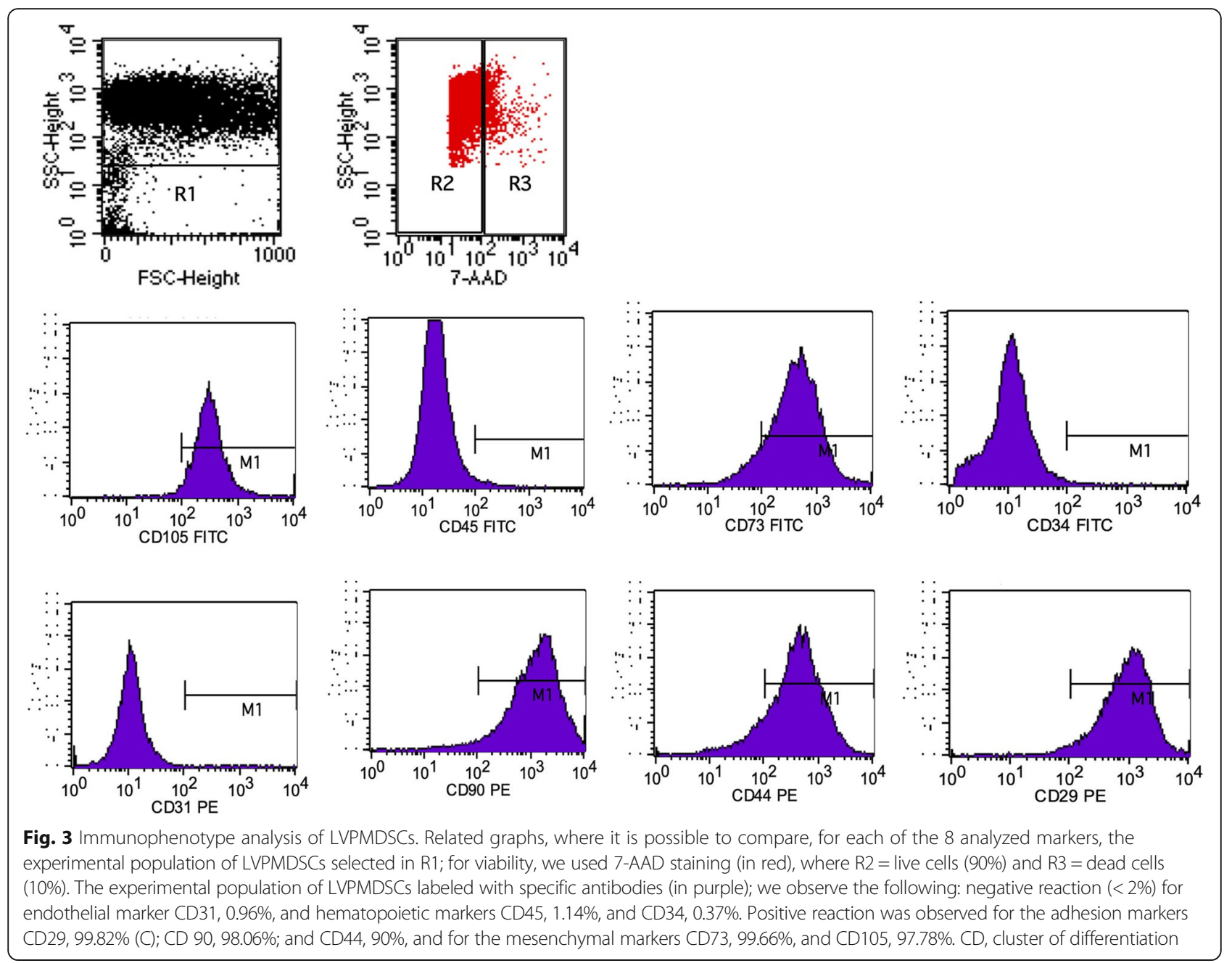

mesenchymal stromal nature of the isolated cells, as well as their multipotency. After 11 days with osteogenic induction, we can observe calcium production in LVPM induced with osteogenic medium (Fig. 5). Based on this observation, we renamed the cells isolated from LVPM as levator veli palatini muscle-derived stromal cells (LVPMDSCs).

\section{In vivo osteogenic potential of LVPMDSC}

The in vivo osteogenic potential of LVPMDSCs was assessed in a calvarial defect model in nonimmunosuppressed Wistar rats. None of the experimental animals died of infection, nor any other complication as a result of surgery or the cell/scaffold transplantation process.

Table 1 Percentage of positive reactivity for each cell strain and for each cell marker used on flow cytometry experiment

\begin{tabular}{llllll}
\hline Marker & F3440-1 (\%) & F3404-1 (\%) & F3420-1 (\%) & F3492-1 (\%) & F3436-1 (\%) \\
\hline CD29 & 99.82 & 95.85 & 95.82 & 99.64 & 98.59 \\
CD73 & 99.66 & 98.82 & 98.82 & 99.04 & 98.87 \\
CD90 & 98.06 & 97.88 & 97.88 & 99.78 & 97.78 \\
CD105 & 97.78 & 94.00 & 93.24 & 90.42 & 89.34 \\
CD44 & 90 & 89.8 & 92.5 & 91.78 & 90 \\
CD31 & 0.96 & 0.80 & 0.80 & 0.76 & 0.97 \\
CD45 & 1.14 & 0.64 & 0.64 & 1.18 & 1.18 \\
CD34 & 0.37 & 0.4 & 0.08 & 0.1 & 0.2 \\
7-AAD & 90 & 96 & 92 & 96 & 98 \\
\hline
\end{tabular}



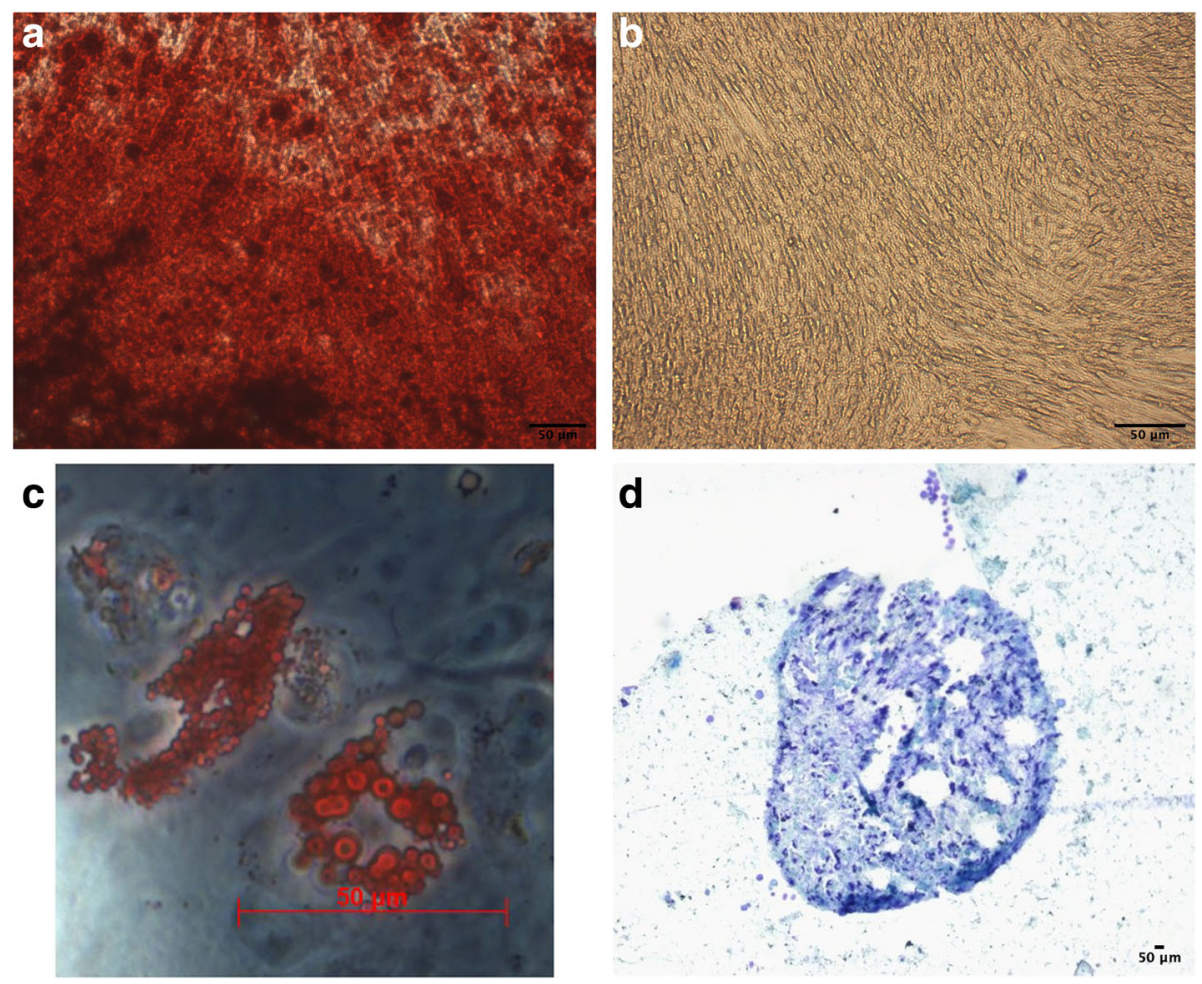

Fig. 4 In vitro staining of LVPMDSCs. Osteogenic differentiation: Alizarin Red S staining revealing calcified extracellular matrix 21 days after osteogenic induction, white arrows shows the calcium deposition (a) and its negative control (b). Adipogenic differentiation: Oil Red-O staining (c). Chondrogenic differentiation: toluidine blue staining (d). Scale bars, $50 \mu \mathrm{m}$

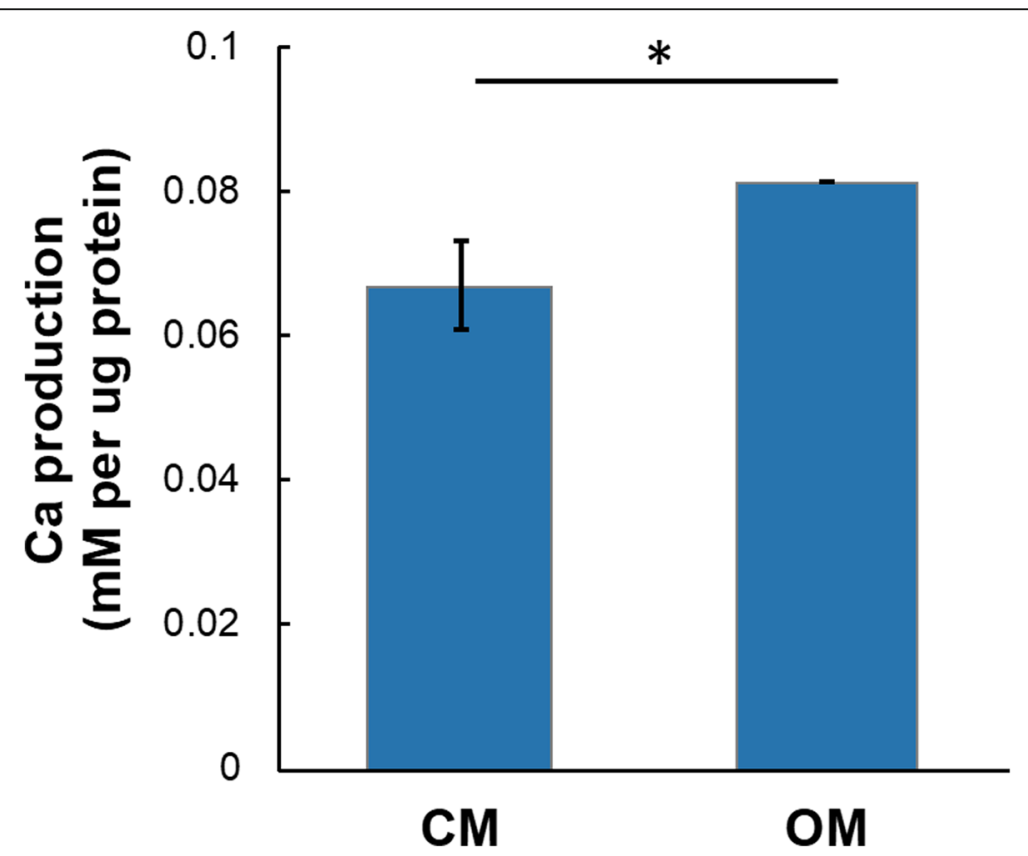

Fig. 5 Cells were cultured with control medium (CM) or osteogenic medium (OM). After 11 days treatment, calcium content was evaluated using a kit. Cells treated with OM showed significantly increased calcium production compared with the cells in CM. * $p<0.05$ by the Student's $t$ test 
Histological examination of the cranial defect 30 days following surgery revealed significantly new bone formation on the RS (scaffold + LVPMDSC) compared to the LS (acellular scaffold) (Fig. 6a, b). The trabeculae of the newly formed bone (woven bone) observed in the RS defects were intermixed with granulation tissue and with remnants of the CellCeram ${ }^{\mathrm{mm}}$ biomaterial. By comparison, the LS defects healed with loose connective tissue exhibiting chronic inflammatory infiltrates, intermingled with larger amounts of scaffold remnant (Fig. 6c, d).

The regenerated bone area quantitatively measured by Image showed the percent area of regenerated bone by

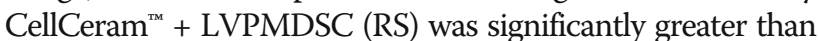
that by Cell Ceram ${ }^{\text {Tw }}$ (LS), $p<0.05$ by Student's $t$ test (Fig. 7).

We also observed positive staining for human nuclei thorough immunohistochemical analysis only on the inflammatory tissue on the RS where the LVPMDSCs were added to the CellCeram ${ }^{\mathrm{Tm}}$ biomaterial. On the LS (acellular scaffold reconstruction), we observed positive reaction only for DAPI staining, without any evidence of human cell proliferation (Fig. 8 and supplementary material Fig. 1).

\section{Discussion}

Initially defined as bone marrow precursors, new evidence suggests that MSCs are present in virtually all organs, possibly playing an important role in tissue maintenance and regeneration [12, 13, 18, 19]. The possibility of using MSCs in regenerative medicine protocols has opened a new field of investigation aiming to find the best sources for obtaining multipotent stem cells, with a specific focus on cells that can be obtained in non- or minimally invasive ways.

In this study, we have demonstrated that LVPM fragments, which can easily be obtained in patients

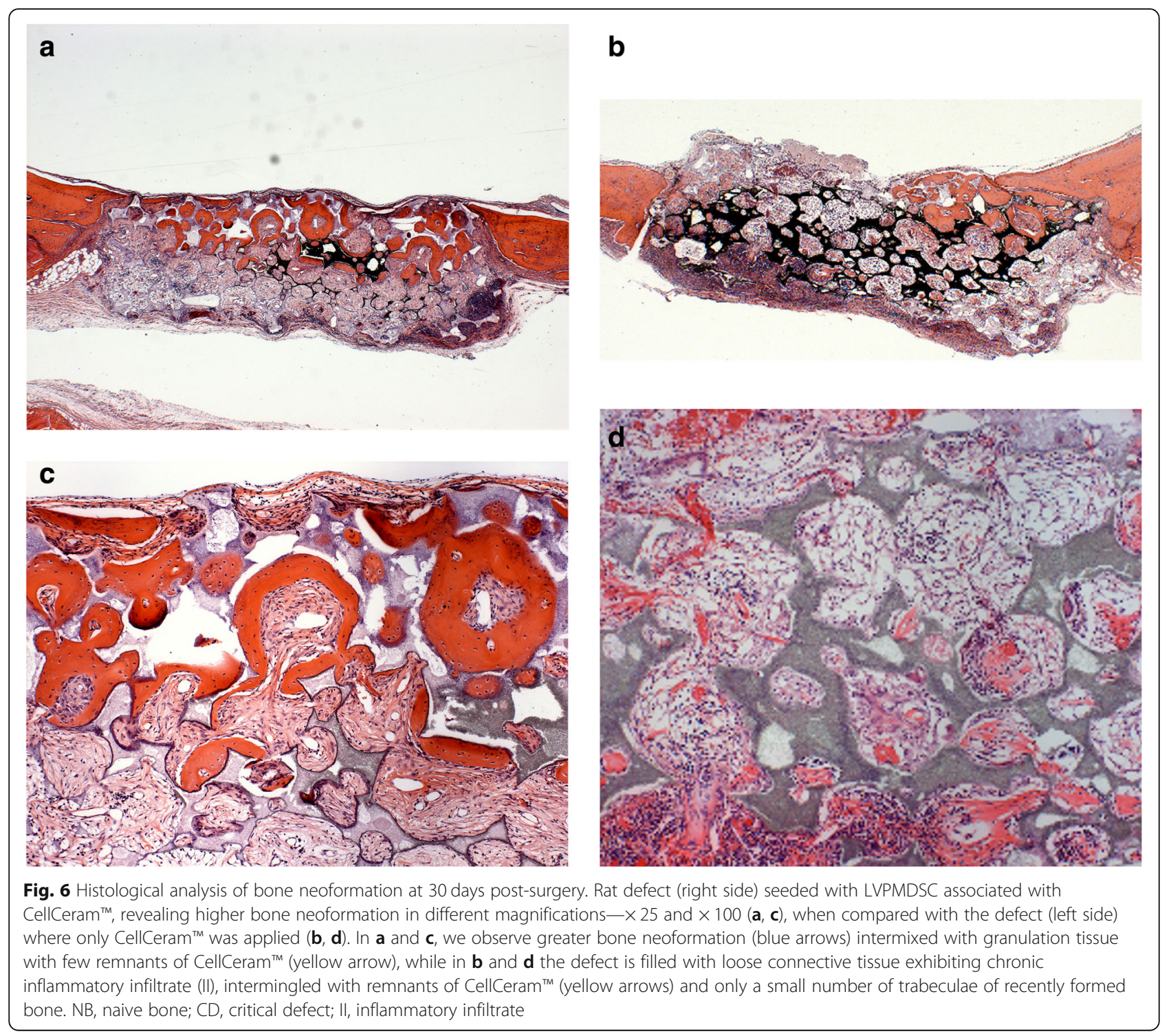




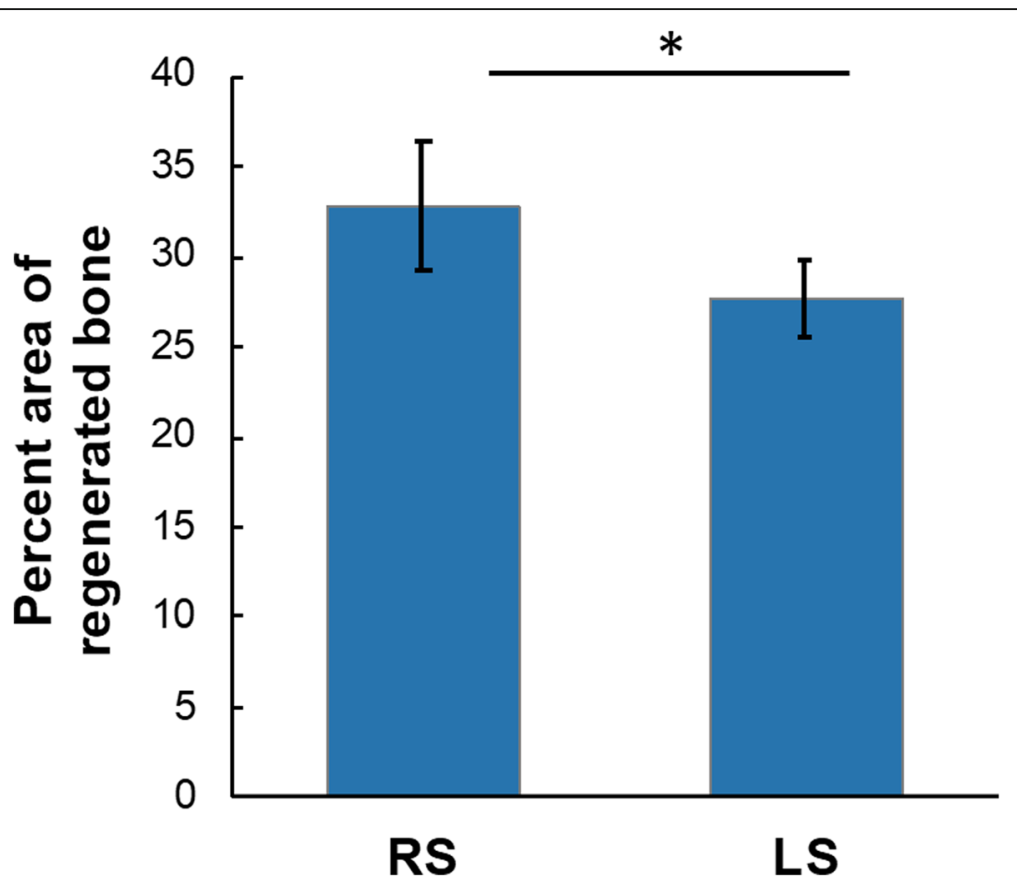

Fig. 7 Regenerated bone was quantitatively measured by ImageJ. The percent area of regenerated bone by CellCeram ${ }^{\text {TM }}+$ LVPMDSC (RS) was significantly greater than that by CellCeram ${ }^{\mathrm{TM}}(\mathrm{LS}) .{ }^{*} p<0.05$ by the Student's $t$ test

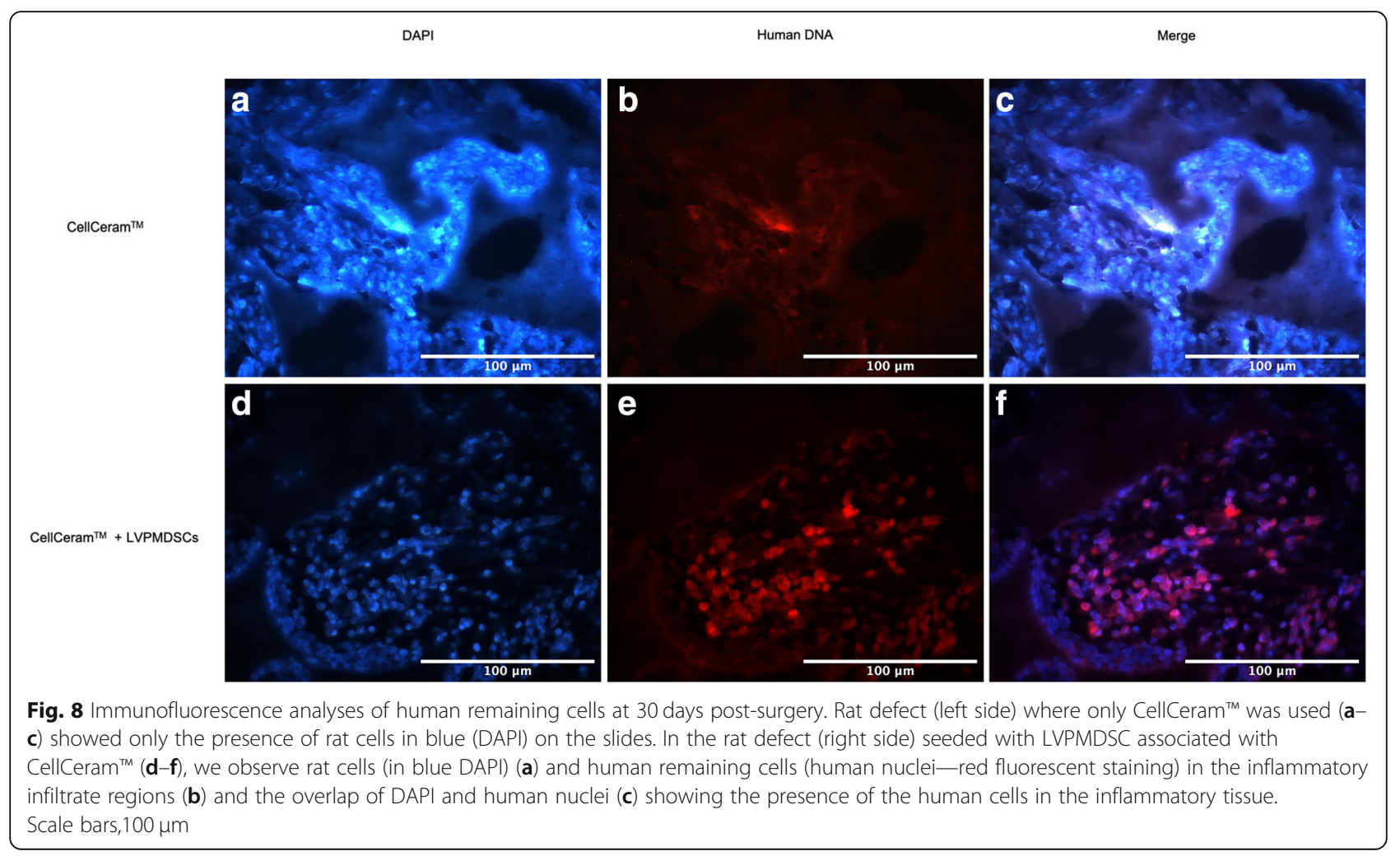


undergoing palatoplasty, represent a novel source of multipotent MSCs. We have therefore begun to refer to these cells, including herein, as levator veli palatini muscle-derived stromal cells (LVPMDSCs).

LVPMDSCs have similar characteristics to the orbicularis oris muscle-derived stem cells (OOMDSCs) obtained from cleft lip and palate patients, which we have previously described $[13,15]$. The similarity between them resides in their immunophenotype: like OOMDSCs, LVPMDSCs were strongly positive for mesenchymal and adhesion cell surface markers, but did not demonstrate the presence of endothelial or hematopoietic markers $[13,15]$.

From a technical standpoint, our results show that the pre-plating technique used here can be applied to isolate stromal cells with similar properties from two distinct sources: orbicularis oris and levator veli palatini muscles. Whether this can be generalized to cells derived from other muscles remains to be investigated, since markers used for cell characterization vary across studies $[20,21]$.

The mesenchymal/multipotential nature of isolated LVPMDSCs in this study was confirmed by the high expression of adhesion and MSC markers in these cells, along with their demonstrated multilineage differentiation potential $[22,23]$. These phenotypic hallmarks were similar to the ones seen in primary MSCs obtained from other sources, such as fat, dental pulp, bone marrow, fallopian tube, orbicular oris muscle, and umbilical cord vein in other studies conducted by our team [13, 24-26].

Such features of LVPMDSCs, in conjunction with their capacity to increase bone formation in vivo when associated with CellCeram ${ }^{\mathrm{Tm}}$ scaffolds, indicate that this cell type has the potential for clinical application, especially in bone tissue engineering protocols being developed to treat complex craniofacial malformations. Our data showed that LVPMDSCs seeded onto CellCeram ${ }^{\text {Tx }}$ scaffolds lead to greater amounts of bone regeneration compared to acellular scaffolds, showing the osteogenic potential of these cells in vivo. Our results are consistent with other studies that have demonstrated how MSCs of alternate origin, when seeded onto biocompatible scaffolds, also lead to higher levels of new bone formation when compared to the use of acellular scaffolds [13, 24, 27, 28]. In a study by Gamblin et al. [29], calcium phosphate granules were implanted in the nude mice muscles with or without human MSC and the chronological events leading to osteoinduction were evaluated. They reported that hMSC induced an early mobilization of circulating monocytes to the implantation site as the presence of macrophages and osteoclasts was significantly upregulated, suggesting their implication in the mechanism of bone formation. They also concluded that human MSC did not participate directly in osteogenesis; rather, they increased the innate immune response and enabled to speed up the mobilization of monocytes to the implantation site, and an upregulation of osteoclasts and macrophages at the implantation site was correlated with increased bone formation due to human MSC associated to calcium phosphate particles. In our study, it is important to highlight that in our in vivo calvaria reconstruction experiments, a positive reaction for human nuclei antibody was observed in defects reconstructed with LVPMDSCs seeded onto CellCeram $^{\mathrm{Tw}}$ scaffolds. In these defects, new bone formation was observed in the middle of the defects while human nuclei were identified in the marginal areas of inflammation. This observation supports the notion that the LPVM DSCs have a paracrine function that may stimulate bone formation within the defect. By comparison, acellular scaffold reconstruction resulted in new bone deposition primarily along the margins of the defect with a paucity of central defect osteogenesis.

Different types of biocompatible scaffolds have been used in tissue engineering research. These include collagen membranes [10, 13], hydroxyapatite [12, 27], and calcium phosphate [30]. Here, we suggest that Cell$\mathrm{Ceram}^{\mathrm{Tm}}$, a biomaterial composed of hydroxyapatite and ß-tricalciumphosphate, is an effective alternative in this tissue engineering paradigm, as its size and threedimensional shape can be custom-synthesized. This enables each CellCeram ${ }^{\text {Tx }}$ scaffold to be individually designed according to the precise anatomical requirements that define any specific bone defect.

We observed no post-surgical complications, such as wound infection or dehiscence, graft rejection, or any other overt sign of gross inflammation. The fact that immunocompetent animals were used in this study, and that these animals underwent xenotransplantation of human multipotent MSCs, suggests that LVPMDSCs helped mitigate an anticipated immunological response in such an experimental setting. This result is consistent with similar prior observations with other types of MSCs, in three previous works by our group [13, 24, 31]. Moreover, it has been reported that MSCs possess immunomodulatory properties [27]. Collectively, these findings suggest that heterologous LVPMDSCs may safely be used in clinical bone tissue engineering protocols without elevated risk of immunologic-mediated inflammatory responses.

Based on our previous experience in clinical trials using deciduous dental pulp stem cells associated with biocompatible scaffolds (Bio-Oss Collagen ${ }^{\circ}$ Geistlish) to reconstruct alveolar clefts (Clinicaltrials.gov: NCT01932164 and NCT03766217), we believe that it will be possible to scale expansion of LVPMDSCs and seed these cells onto custom three-dimensional printed scaffolds as the foundation of a clinically applicable bone tissue engineering strategy 
[12]. Because LVPMDSCs and deciduous dental pulp stem cells have similar in vitro and in vivo properties, we are convinced that these two distinct yet related cell populations will behave similarly in the setting of major bone reconstructive challenges.

Like the protocol that was implemented in our autologous dental pulp stem cell alveolar cleft reconstruction clinical trial [12], we intend to collect levator veli palatine muscle samples during the palatoplasty surgery, send the samples to the laboratory, isolate the LVPMDS, seed them onto scaffolds, and return a "Bioengineering Kit" (composed of the LVPMDSC/scaffold combination) back to the operating room for implantation. The same approach can be used in the future for heterologous grafts. The use of this bioengineering "kit" can reduce morbidity by eliminating the need to for autogenous grafts and separate donor site surgery. Surgeons who treat congenital craniofacial differences always try to decrease the number of operations in children requiring complex or staged reconstruction [10]. The potential to minimize the numbers of required surgeries and, by extension, surgical morbidity by using MSCs seeded onto various scaffolds to generate new bone formation is an exciting prospect [10-12].

\section{Conclusion}

In summary, our study suggests that, in the future, LVPMDSCs associated with CellCeram ${ }^{\mathrm{Tm}}$ scaffolds may be used as a substitute for autologous bone grafting in craniofacial syndromes, specifically those that include cleft palate in their phenotype. In patients with Treacher-Collins, Goldenhar, or other syndromes that may use distraction and/or bone grafting procedures, autologous LVPMDSCs in association with CellCeram ${ }^{\text {tu }}$ may provide a viable clinical alternative. The isolation and characterization of LVPMDSCs open new opportunities for the use of these cells in bone reconstruction.

To our knowledge, this is the first study to describe the isolation, in vitro expansion, and multilineage differentiation potential of mesenchymal stromal cells derived from levator veli palatini muscle. These cells enhance bone regeneration in vivo when associated with CellCeram $^{\text {Tx }}$. Thus, our results suggest that these cells are suitable for future applications in bone tissue engineering for craniofacial diseases.

\section{Supplementary Information}

The online version contains supplementary material available at https://doi. org/10.1186/s13287-020-02017-7

Additional file 1. Supplementary Materials.

\section{Abbreviations}

OOM: Orbicularis oris muscle; CL/P: Cleft lip and palate; MSCs: Mesenchymal stem cells; LVPM: Levator veli palatini muscle; GMP: Good practices of manipulation; ANVISA: Agência Nacional de Vigilância Sanitária, Brazil (Brazilian National Sanitary Vigilance Agency); DMEM/F-12: Dulbecco's modified Eagle's medium/HAMs F-12; FBS: Fetal bovine serum; PBS: Phosphate-buffered saline; LVPMDSCs: Levator veli palatine musclederived stem cells

\section{Acknowledgements}

The authors would like to express their gratitude to CNPq, FAPESP, Programa de Apoio ao Desenvolvimento Institucional do SUS (PROADI-SUS), and Hospital Sírio-Libanês for sponsoring this study and for motivating studies to develop new tissue engineering strategies to be used in patients with craniofacial malformations. We also would like to thank Regenerative Bioengineering and Repair Laboratory, Department of Surgery, David Geffen School of Medicine at University of California, Los Angeles, for the use of its facilities and for the collaboration of their researchers to carry out this study.

\section{Authors' contributions}

Bueno D F carried out the conceptualization of the study and its design, isolated the LVPMDSC, prepared the scaffold with LVPMDSC, did the in vivo experiments, did the histological analysis, did the immunohistochemistry experiments, did the data analysis, and wrote the manuscript. Kobayashi GS helped carry out the LVPMDSC isolation, characterization, and expansion; helped with the flow cytometry analysis of LVPMDSC; and helped during the in vivo experiments. Pinheiro CCG carried out the LVPMDSC flow cytometry analysis and helped with the images for the manuscript. Tanikawa D Y S collected the LVPM during the palatoplasty surgeries at Hospital Municipal Infantil Menino Jesus and helped to draft the manuscript. Raposo-Amaral C E collected the LVPM during the palatoplasty surgeries at SOBRAPAR Hospital and helped to draft the manuscript. Rocha D L collected the LVPM during the palatoplasty surgeries at Hospital Municipal Infantil Menino Jesus and helped with the conceptualization of the manuscript. Ferreira J R M helped with the LVPMDSC isolation, characterization, and expansion. Shibuya Y helped with the histological preparation and quantitative analysis. Hokugo A helped with the histological preparation, quantitative analysis, and immunohistochemistry analysis and helped to write the manuscript. Jarrahy R helped with the conceptualization of the study and its design, helped with the data analysis, and helped to write the manuscript. Zuk P. A contribution includes resources, image editing, and data validation of the laboratory processes; she also helped with the immunohistochemistry experiments and data analysis. Bueno M R P helped with the conceptualization of the study and its design and data analysis. The authors read and approved the final manuscript.

\section{Funding}

This study was funded by Hospital Sírio-Libanês and by Brazilian Ministry of Health number 25000.009809/2018-65 (PROADI-SUS project of development of tissue bioengineering strategies to treat patients with craniofacial malformations).

\section{Availability of data and materials}

The corresponding author had full access to all the data in the study and had final responsibility for the decision to submit for publication. Please contact author for data requests.

Ethics approval and consent to participate

This project is approved by Animal Ethics Committee of Hospital SírioLibanês number (CEUA 2017-04) and Ethics Committee of Instituto de Biociências -USP.

\section{Consent for publication}

Consent was received from the patients and/or legally responsible person.

\section{Competing interests}

The authors declare that they have no competing interests.

\section{Author details}

${ }^{1}$ Hospital Sírio-Libanês, Instituto de Ensino e Pesquisa, São Paulo, SP, Brazil. ${ }^{2}$ Hospital Municipal Infantil Menino Jesus, São Paulo, SP, Brazil. ${ }^{3} U$ niversidade de São Paulo - USP, Instituto de Biociências, Centro de Pesquisa sobre o Genoma Humano e Células-Tronco, São Paulo, SP, Brazil. ${ }^{4}$ Hospital SOBRAPAR, Campinas, SP, Brazil. Instituto Militar de Engenharia (IME), Departamento de Ciências de Materiais, Programa de Pós-graduação em 
Ciências de Materiais, Rio de Janeiro, RJ, Brazil. ${ }^{6}$ Division of Plastic and Reconstructive Surgery, David Geffen School of Medicine, University of California Los Angeles (UCLA), Los Angeles, CA, USA.

Received: 13 July 2020 Accepted: 4 November 2020

Published online: 25 November 2020

\section{References}

1. Gorlin RJ, Cohen MMJ, Hennekam RCM. Orofacial clefting syndrome: general aspects. In: Syndromes of the head and neck; 2001. p. 850-76.

2. Vanderas AP. Incidence of cleft lip, cleft palate, and cleft lip and palate among races: a review. Cleft Palate J. 1987;24(3):216-25.

3. Murray JC, Daack-Hirsch S, Buetow KH, Munger RG, Espina L, Paglinawan N, et al. Clinical and epidemiologic studies of cleft lip and palate in the Philippines. Cleft Palate-Craniofacial J. 1997;34(1):7-10.

4. Jones MC. Etiology of facial clefts: prospective evaluation of 428 patients. Cleft Palate J. 1988;1(25):16-20.

5. Thompson JT, Anderson PJ, David DJ. Treacher Collins syndrome: protocol management from birth to maturity. J Craniofac Surg. 2009;20(6):2028-35.

6. Canter HI, Kayikcioglu A, Saglam-Aydinatay B, Kiratli PO, Benli K, Taner T, et al. Mandibular reconstruction in goldenhar syndrome using temporalis muscle osteofascial flap. J Craniofac Surg. 2008:19(1):165-70.

7. Younger EM, Chapman MW. Morbidity at bone graft donor sites. J Orthop Trauma. 1989:3(3):192-5.

8. Esparza J, Hinojosa J. Complications in the surgical treatment of craniosynostosis and craniofacial syndromes: apropos of 306 transcrania procedures. Childs Nerv Syst. 2008;24(12):1421-30.

9. Alonso N, Tanikawa DYS, Freitas R da S, Canan, Lady, Ozawa TO, Rocha DL. Evaluation of maxillary alveolar reconstruction using a resorbable collagen sponge with recombinant human bone morphogenetic protein-2 in cleft lip and palate patients. Tissue Eng Part C Methods. 2010;16(5):1183-9. Available from: http://www.liebertonline.com/doi/abs/10.1089/ten.tec.2009. 0824. [cited 2016 Nov 6].

10. Gimbel M, Ashley RK, Sisodia M, Gabbay JS, Wasson KL, Heller J, et al. Repair of alveolar cleft defects: reduced morbidity with bone marrow stem cells in a resorbable matrix. J Craniofac Surg. 2007;18(4):895-901 Available from: http://www.ncbi.nlm.nih.gov/pubmed/17667684. [cited 2016 Nov 6].

11. Hibi H, Yamada Y, Ueda M, Endo Y. Alveolar cleft osteoplasty using tissueengineered osteogenic material. Int J Oral Maxillofac Surg. 2006;35(6):551-5.

12. Tanikawa DYS, Pinheiro CCG, Almeida MCA, Oliveira CRGCM, Coudry R de A, Rocha DL, et al. Deciduous dental pulp stem cells for maxillary alveolar reconstruction in cleft lip and palate patients. Stem Cells Int. 2020;2020:1-9.

13. Bueno DF, Kerkis I, Costa AM, Martins MT, Kobayashi GS, Zucconi E, et al. New source of muscle-derived stem cells with potential for alveolar bone reconstruction in cleft lip and/or palate patients. Tissue Eng Part A. 2009; 15(2):427-35 Available from: http://www.liebertonline.com/doi/abs/10.1089/ ten.tea.2007.0417. [cited 2016 Nov 9].

14. Trier WC, Dreyer TM. Primary von Langenbeck palatoplasty with levator reconstruction: rationale and technique. Cleft Palate J. 1984;4(21):254-62.

15. Pinheiro CCG, Leyendecker Junior A, Tanikawa DYS, Ferreira JRM, Jarrahy R, Bueno DF. Is there a noninvasive source of MSCs isolated with GMP methods with better osteogenic potential? Stem Cell Int. 2019;1:1-14. https://doi.org/10.1155/2019/7951696.eCollection2019.

16. Chen $Y, Y u Q, X u C B$. A convenient method for quantifying collagen fibers in atherosclerotic lesions by imagej software. Int J Clin Exp Med. 2017; 10(10):14904-10.

17. Schneider CA, Rasband WS, Eliceiri KW. NIH image to ImageJ: 25 years of image analysis. Nat Methods. 2012;9(7):671-5.

18. Caplan Al. Mesenchymal stem cells: cell-based reconstructive therapy in orthopedics. Tissue Eng. 2005;11(7-8):1198-211.

19. Zuk PA, Zhu M, Ashjian P, De Ugarte DA, Huang Jl, Mizuno H, et al. Human adipose tissue is a source of multipotent stem cells $\square$ D. Mol Biol Cell. 2002; 13:4279-95.

20. Sun JS, Wu SYH, Lin FH. The role of muscle-derived stem cells in bone tissue engineering. Biomaterials. 2005;26(18):3953-60.

21. Sinanan ACM, Buxton PG, Lewis MP. Muscling in on stem cells. Biol Cell. 2006:98(4):203-14.

22. Dominici M, Le Blanc K, Mueller I, Slaper-Cortenbach I, Marini F, Krause D, et al. Minimal criteria for defining multipotent mesenchymal stromal cells. The International Society for Cellular Therapy position statement.
Cytotherapy. 2006;8(4):315-7 Available from: http://www.ncbi.nlm.nih.gov/ pubmed/16923606.

23. Viswanathan S, Shi Y, Galipeau J, Krampera M, Leblanc K, Martin I, et al. Mesenchymal stem versus stromal cells: International Society for Cell \& Gene Therapy (ISCT ${ }^{\oplus}$ ) Mesenchymal Stromal Cell committee position statement on nomenclature. Cytotherapy. 2019;21(10):1019-24. https://doi. org/10.1016/j.jcyt.2019.08.002

24. de Mendonca CA, Bueno DF, Martins MT, Kerkis I, Kerkis A, Fanganiello RD, et al. Reconstruction of large cranial defects in nonimmunosuppressed experimental design with human dental pulp stem cells. J Craniofac Surg. 2008:19(1):204-10.

25. Zucconi E, Vieira NM, Bueno CR Jr, Secco M, Jazedje T, Costa Valadares M, et al. Preclinical studies with umbilical cord mesenchymal stromal cells in different animal models for muscular dystrophy. J Biomed Biotechnol. 2011; 2011:715251 Available from: http://www.ncbi.n/m.nih.gov/entrez/query. fcgi?cmd=Retrieve\&db=PubMed\&dopt=Citation\&list_uids=21785565.

26. Jazedje T, Bueno DF, Almada BVP, Caetano H, Czeresnia CE, Perin PM, et al. Human fallopian tube mesenchymal stromal cells enhance bone regeneration in a xenotransplanted model. Stem Cell Rev Rep. 2012;8(2): 355-62.

27. Mankani MH, Afghani S, Franco J, Launey M, Marshall S, Marshall GW, et al. Lamellar spacing in cuboid hydroxyapatite scaffolds regulates bone formation by human bone marrow stromal cells. Tissue Eng - Part A. 2011; 17(11-12):1615-23.

28. Raposo-Amaral CE, Bueno DF, Almeida AB, Jorgetti V, Costa CC, Gouveia CH, et al. Is bone transplantation the gold standard for repair of alveolar bone defects? J Tissue Eng. 2014;5:2041731413519352. https://doi.org/10.1177/ 2041731413519352

29. Gamblin AL, Brennan MA, Renaud A, Yagita H, Lézot F, Heymann D, et al. Bone tissue formation with human mesenchymal stem cells and biphasic calcium phosphate ceramics: the local implication of osteoclasts and macrophages. Biomaterials. 2014;35(36):9660-7.

30. Goshima J, Goldberg V, Caplan A. The origin of bone formed in composite grafts of porous calcium phosphate ceramic loaded with marrow cells. Clin Orthop Relat Res. 1991;269:274-83.

31. Jazedje T, Perin PM, Czeresnia CE, Maluf M, Halpern S, Secco M, et al. Human fallopian tube: a new source of multipotent adult mesenchymal stem cells discarded in surgical procedures. J Transl Med. 2009;7:46 Available from: http://www.pubmedcentral.nih.gov/articlerender.fcgi?artid= 2714040\&tool=pmcentrez\&rendertype=abstract.

\section{Publisher's Note}

Springer Nature remains neutral with regard to jurisdictional claims in published maps and institutional affiliations.

Ready to submit your research? Choose BMC and benefit from:

- fast, convenient online submission

- thorough peer review by experienced researchers in your field

- rapid publication on acceptance

- support for research data, including large and complex data types

- gold Open Access which fosters wider collaboration and increased citations

- maximum visibility for your research: over $100 \mathrm{M}$ website views per year

At BMC, research is always in progress.

Learn more biomedcentral.com/submission 